\title{
LER PARA CRER: ALGUMAS REFLEXÕES SOBRE AS LEGENDAS E AS IMAGENS NAS CANTIGAS DE SANTA MARIA
}

\section{READ IS BELIEVE: SOME REFLECTIONS ABOUT THE SUBTITLES AND IMAGES IN THE CANTIGAS DE SANTA MARIA}

\author{
Guilherme Antunes Junior ${ }^{1}$ \\ Universidade Federal do Rio de Janeiro
}

Resumo: O presente trabalho busca refletir sobre as relações entre texto e imagem nas Cantigas de Santa Maria, manuscrito em galego-português, sob patrocínio de Alfonso X, monarca de Castela e Leão do século XIII. A partir da comparação, busco demonstrar as incoerências entre as miniaturas de três cantigas com seus respectivos rótulos. A conclusão é de que os discursos visuais e textuais são dialéticos, interdependentes ou autônomos, sempre a depender dos contextos de produção e os sentidos históricos da fonte.

Palavras-chave: Cantigas de Santa Maria; Iconografia; Discurso.

1 guiantunesjr@yahoo.com.br 
Abstract: This paper seeks to reflect on the relationship between text and image in the Cantigas de Santa Maria, manuscript in Galician-Portuguese, under the patronage of Alfonso X, monarch of Castile and Leon of the 13th century. From the comparison, I try to demonstrate the inconsistencies between the miniatures of three cantigas with their respective captions. The conclusion is that visual and textual discourses are dialectical, interdependent or autonomous, always depending on the contexts of production and the historical meanings of the source.

Keywords: Cantigas de Santa Maria; Iconography; Discourse.

\section{INTRODUÇÃO}

As Cantigas de Santa Maria (CSM) formam um conjunto documental medieval reconhecido pelo seu caráter multifacetário, sobretudo, por agrupar diferentes estruturas narrativas em seu corpus: nos campos da poesia, da música, da prosa e da iconografia. Há quatro manuscritos preservados das CSM, datados em sua maioria, provavelmente, do século XIII. Eles estão nomeados como códice j. b. 2 (E), da Biblioteca El Escorial; T. j. I (T), também de El Escorial; o códice de Toledo (To), hoje na Biblioteca Nacional de Madrid; e o manuscrito da Biblioteca Nazionale de Florença (F). Atribuídas ao mecenato do monarca Alfonso X, de alcunha o Sábio, as CSM foram produzidas por um taller de especialistas, muito embora ainda haja discussões quanto à precisão das datas, entre os anos de 1264 e 1284, interrompidas pela morte do rei-Sábio (MONTOYA MARTÍNEZ, 1987, p. 377). As CSM foram escritas em galegoportuguês, tanto o texto poético quanto as legendas.

O interesse dos pesquisadores pelas CSM é bastante heterogêneo em função do próprio códice, cuja particularidade "multimídia", em diferentes linguagens, permite também variadas abordagens dos mais diversos campos epistêmicos. Não apenas linguistas, mas também historiadores, arqueólogos, literatos, historiadores da arte, filólogos etc., estão em permanente diálogo. Além disso, as análises não são isoladas, levando os profissionais a buscarem interfaces, permitindo trocas entre áreas acadêmicas e campos de investigação. 
As miniaturas constituem um interesse principalmente dos historiadores por conta da riqueza de detalhes e por testemunharem representações do cotidiano medieval decoradas em aproximadamente 2.850 imagens. $^{2}$ Além dessa monumental riqueza pictórica, as legendas - também chamadas de cartelas ou rótulos - são frases breves em prosa inscritas sobre as miniaturas de dois dos quatro cancioneiros de Alfonso X, o Códice Rico e o Códice de Florença, e compreendem uma maneira de narrar complementar, para além dos poemas do cancioneiro marial.

Também escritas em galego-português, as legendas podem estar subordinadas às imagens, oferecendo aos pesquisadores desatentos uma conexão imediata e "ordenada" de uma sobre a outra, porém essa relação não é tão tangível como imaginamos. As legendas, não só porque foram presumivelmente inseridas depois de terminadas as miniaturas, mas porque o relato em que eles se baseavam para o "resumo" nem sempre tinha a mesma origem daqueles que produziam o texto poético. $\mathrm{O}$ mesmo ocorre com as iconografias.

Neste espaço, proponho algumas reflexões sobre as relações entre as legendas e as imagens, em especial as das cantigas 17, 88 e 32, buscando evidenciar os aspectos contrastantes entre as linguagens pictóricas e textuais com as do narrar, além de procurar responder, ainda que parcialmente, à seguinte questão: quais as funções das legendas nas CSM? Em um universo com cerca de 400 cantigas, selecionei aquelas cuja evidente discrepância entre rótulos e imagens possibilitem pensar sobre o que deve ser narrável, evidenciado e testemunhável, em contraste com o que pode manter-se exclusivo ao aspecto pictórico, sujeito, portanto, aos olhares e julgamentos do espectador.

\footnotetext{
2 Utilizo o termo imagem, iconografia e miniatura como sinônimos, embora reconheça que há certa imprecisão nesta escolha, mas, ao mesmo tempo, torna-se pouco útil abordar esse debate aqui. Sobre as discussões acerca das terminologias empregadas para análise dos códices medievais iluminados ver: FERNÁNDEZ FERNÁNDEZ, 2019, p. 191-206.
} 
De fato, todas as cantigas têm algum grau de desequilíbrio entre o enunciado da legenda e a narrativa imagética. Entretanto, as estratégias discursivas construídas nas relações texto-imagem possibilitam ao historiador refletir sobre como a elaboração do livro transcende as funções do objeto e reelabora os sentidos do fazer e do saber.

Para tanto, utilizo apenas o Códice Rico - deixo o códice de Florença para outra ocasião - por meio da publicação de Walter Mettmann, ocorrida entre os anos de 1959 e 1972, relançadas entre 1986 e 1989, e o fac-símile do mesmo Códice Rico, editado pela Edilán em 1979. Já para as legendas, privilegio a proposta de José-Martinho Montero Santalha, cujo trabalho foi revisar as edições que publicaram as legendas, propondo nova grafia e reavaliando os critérios de transcrição desses textos.

\section{O INTERESSE PELAS LEGENDAS}

Não pretendo fazer um balanço histórico acerca das publicações das legendas e as análises críticas associados a elas nos estudos das CSM. Para tanto, Montero Santalha tomou para si essa tarefa de forma satisfatória ao apontar os equívocos na transcrição do léxico do cancioneiro alfonsino por outros autores (2000, p. 507-552). Irei me concentrar no processo de produção das cantigas referentes às miniaturas e as interdependências dessas com os textos dos rótulos. Vale ressaltar que o caráter multiforme das CSM permite associar diferentes narrativas que se interconectam: a música, a poesia, a iconografia e a prosa, como mencionei. Um dos primeiros autores a trabalhar as CSM de maneira global, abordando essas linguagens variadas, foi José Guerrero Lovillo (1949), que enfatizou os aspectos arqueológicos das imagens. Ou seja, preocupou-se em estudar a cultura material presente nas iconografias, considerando vários detalhes contidos nas pinturas, como vestuário, 
armamento, arquitetura, ícones religiosos, trabalho, etc., verificando cada objeto presente nas miniaturas e mapeando os que eram possivelmente de uso cotidiano e efetivo das pessoas. Além disso, Lovillo foi o primeiro que publicou as legendas do Códice Rico integralmente, apesar de apresentar “... alguns aspectos insatisfatórios desde o ponto de vista filológico, embora para fins de estudo histórico, artístico, ou mesmo literário, resultem suficientemente exatas..." (MONTERO SANTALHA, 2002, p. 512). O trabalho de Lovillo continua sendo de imenso valor para os interessados nas CSM.

Outro trabalho referencial surgiu alguns anos depois pelas mãos de Menéndez-Pidal, em 1962, no contexto das discussões sobre o processo de produção das CSM, em especial das imagens. O autor espanhol se debruçou sobre as etapas de elaboração das miniaturas no taller alfonsino, desde o ponto mais simples, que envolvia o corte do pergaminho, do desenho que dividia a folha em colunas, até a pintura mais complexa das figuras humanas (MENÉNDEZ-PIDAL, 1962, p. 36-38). Embora não se concentre especificamente nas legendas, Menéndez-Pidal contribuiu para entendermos como funcionava o ciclo criativo de um taller medieval, com divisões de tarefas baseadas na qualidade técnica e no prestígio manufatureiro. As abordagens subsequentes foram refazendo o percurso do historiador espanhol e reelaborando problematizações sobre o momento em que as vinhetas eram fixadas sobre as miniaturas e, sobretudo, porque as imagens dependiam de uma prosa curta. As reflexões foram no sentido de complexificar as relações texto e imagem, não como simples decoração, mas como discursos em um espaço em que cultura visual não é soberana (KELLER, 1976; CHICO PICAZA, 1986; SCARBOROUGH， 1987; GARCÍA CUADRADO, 1992; SÁNCHEZ AMEIJEIRAS, 2002; CORTI, 2011). O plano narrativo, por conseguinte, é ressignificado na medida em que o pictórico e o escrito se complementam e, não raras vezes, se contrapõem. 
Em relação às legendas, enquanto retórica visual em língua galegoportuguesa, e também como uma maneira de narração do milagre poético, não foram elaboradas somente a partir do texto da cantiga, mas provavelmente como uma etapa intermediária da iluminação do manuscrito (PARKINSON, JACKSON, 2006, p. 160-161). Isso quer dizer que, após o término da miniatura, um colaborador "descrevia" em poucas palavras o que representava a cena, tendo a história do milagre (ou o loor) e a própria imagem como referências. Há quem afirme que os castelhianismos existentes nas legendas evidenciam que o processo de elaboração dos rótulos poderia ter sido executado por "operários" não familiarizados com o galego-português (MARIÑO PAZ, 2018, p. 40). Embora este trabalho aborde gêneros narrativos distintos, a prosa e a imagem, as relações entre ambas revelam processos comparáveis de criação, pois aqueles que elaboraram as legendas precisam dar coerência aos elementos visuais. Segundo Rodríguez Alemán (2003), o que caracteriza a narração é a existência de “... unos elementos morfológicos o semánticos y unos nexos que crean continuidad en el relato, que enlazan los temas, para dar sentido a todas las partes" (RODRÍGUEZ ALEMÁN, 2003, p. 56). São as descontinuidades e os paradoxos entre uma forma e outra de narrar que tornam as CSM um objeto complexo e rico em camadas discursivas.

\section{RÓTULOS E IMAGENS}

As CSM têm uma epígrafe que também é considerada geralmente como um título da cantiga. Na cantiga 17, lê-se: Esta é de como Santa María guardou de mórte a onrrada dona de Roma a que o démo acusou pola fazer queimar. Trata-se de uma relação de incesto entre uma mulher identificada como "dama de Roma" e seu próprio filho. Ao perder o marido, a mulher romana passou a se relacionar sexualmente com o seu filho e, dessa conjunção, ela engravidou, “... mas mal 
conórto dun fillo prendeu que del avía, que a fez prennada" (ALFONSO X, 1959, p. 52). Da relação incestuosa, nasceu uma criança que foi assassinada pela própria mãe, jogada em uma privada, sem que ninguém soubesse “... mató-o dentr' en sa cas' ensserrada" (ALFONSO X, 1959, p. 52). Como uma forma de argúcia, o Diabo tomou a forma de um homem sábio “... tornou-s' en forma d' óme sabedor (ALFONSO X, 1959, p. 52), e procurou o imperador para denunciá-la. O monarca não acreditou na história e convocou a dama para que se explicasse, e o Diabo deveria comparecer também. Foi determinado o prazo de três dia para que a dama explicasse o ocorrido. Caso fosse declarada culpada, ela seria punida com a decapitação, “ $D$ ' oj' a tres días, u non aja al, venna provar o maestr' este mal; se non, a tésta lle seja tallada" (ALFONSO X, 1959, p. 53). Confessando seu crime à Virgem Maria, a dama de Roma pediu para que a protegesse, angustiada pela possibilidade da punição. Maria respondeu para que não se preocupasse que tudo o que se passou fora um ardil do demônio. Após o prazo solicitado, a dama se apresentou frente ao monarca, mas o Diabo não reafirmou as acusações e, incapaz, fugiu pelo telhado sorrateiramente, "... e derribou do teit' ũa braçada" (ALFONSO X, 1959, p. 54).

Quando se observa a primeira vinheta, nota-se que os recursos visuais tentam condensar diversos elementos em uma só cena, fragilizando a descrição textual da legenda: 


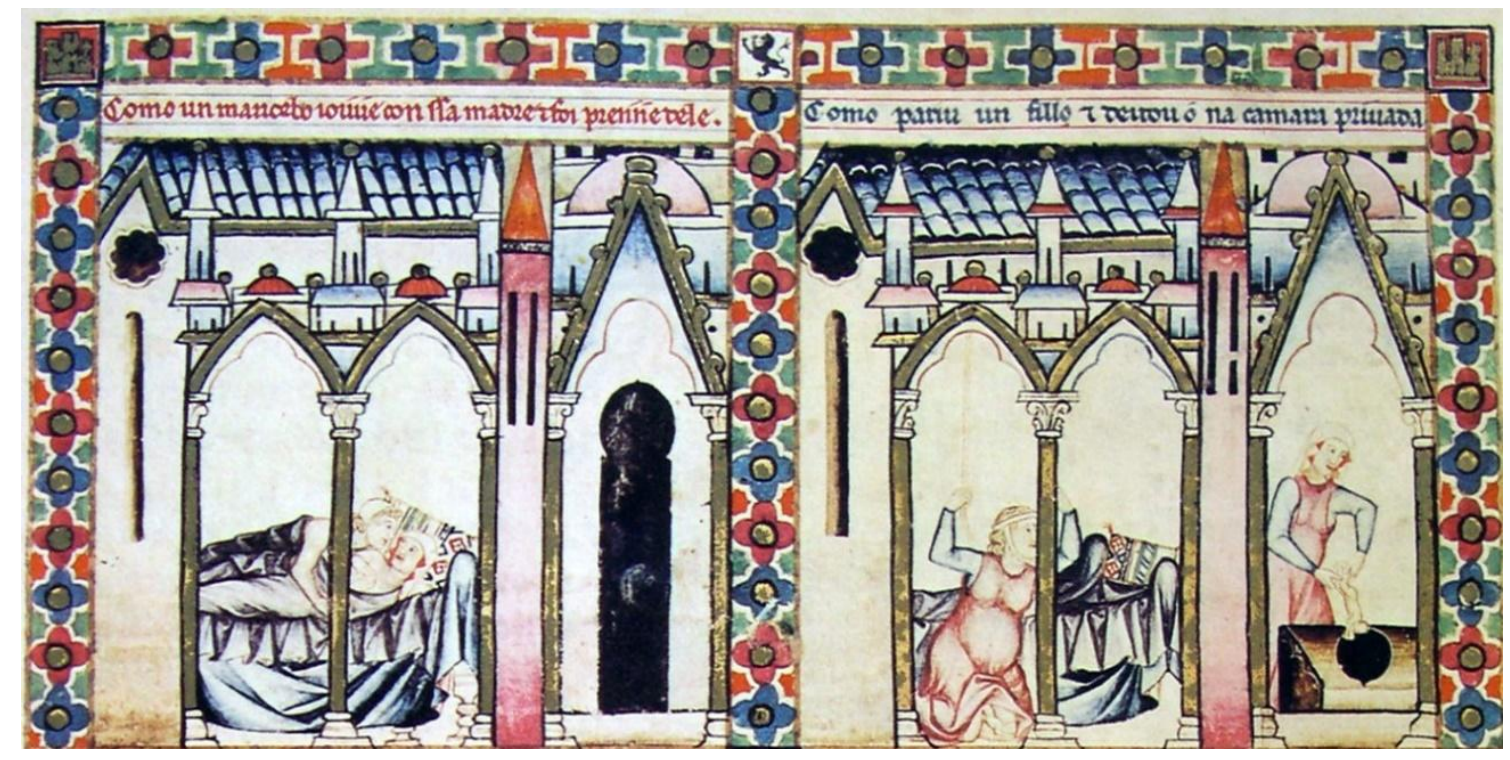

Imagem 01: cantiga 17, As Cantigas de Santa Maria - Códice Rico de El Escorial T-I-1 - E2, f. 29v, miniaturas $1 \mathrm{~A}$ e $2 \mathrm{~B}$

Diante da variação de objetos iconográficos, o miniaturista optou por legendar a cena destacando que o ato sexual teve como consequência a gravidez dela: "Como um mancebo jouve com sa madre, e foi prenhe dele" (MONTERO SANTALHA, 2002, p. 44) ${ }^{3}$. No canto direito, escondido no vão da porta, uma figura escura observa o que está acontecendo: trata-se do Diabo matizado por uma coloração escura, quase uma mancha. A informação de que o demônio testemunhou a cena aparece no verso 10 e na própria miniatura, mas foi obliterada na legenda, "En Roma foi, ja houve tal sazôn, que ũa dona mui de coraçôn amou a Madre de Déus; mas entôn sofreu que fosse do démo tentada" (ALFONSO X, 1959, p. 52). A presença do Diabo sugere que a dama foi tentada a fazer sexo com seu próprio filho, porém, ao mesmo tempo, o miniaturista ignorou a informação de que ela foi devota de Maria, "amou a Madre de Déus", optando por expor o pecado já na primeira vinheta. Já na cena seguinte, a continuidade da narrativa visual ocorre com a manutenção da mesma arquitetura e os mesmos objetos. No entanto, a sequência dos fatos se dá pela divisão da segunda vinheta em duas partes: a dama aparece parindo a criança e, no

3 "Como um jovem deitou com sua mãe e engravidou dele". 
mesmo espaço, mas divididos por uma coluna, a criança já nascida é jogada em uma privada. Segundo o rótulo da miniatura: "Como pariu um filho e deitou-o na cámara privada" (MONTERO SANTALHA, 2002, p. 44) ${ }^{4}$. Além disso, sabemos de que se trata da mesma pessoa protagonizando o ato, por conta da fisionomia e do indício de que são as mesmas roupas. Encaixar dois atos em uma mesma vinheta induz o espectador a imaginar uma curta duração de tempo, um ato contínuo entre um fato e outro.

Já a cantiga 88 narra a história de um médico que era muito reconhecido por sua profissão e por ser também letrado. A epígrafe resume o conteúdo da cantiga da seguinte forma: "Como Santa María fez a un físico que se metera monje que comesse das vidas que os outros monjes comían, que a el soían mui mal saber" $\left(\right.$ ALFONSO X, 1959, p. 253) ${ }^{5}$. Como havia se acostumado a comer bem quando ainda não era monge, o médico passou a ser privado da gula, tendo que se alimentar de pouca ração como os outros monges. Decidido a sair do monastério, a Virgem apareceu no mosteiro e deu de comer a cada religioso, menos ao médico. Sem saber o porquê, Maria o advertiu sobre murmurar durante as refeições, "Diss' ela: Non é pensado que desto póssas fillar, se non leixas téu cuidado fól que te faz mal cuidar" (ALFONSO X, 1959, p. 255). O médico se arrependeu e prometeu se dedicar à ordem cisterciense.

Quando observamos as imagens, percebe-se que as assimetrias com o texto da legenda surgem quando se é necessário construir uma representação do médico letrado:

\footnotetext{
4 "Como pariu um filho e o jogou na privada".

5 "Esta é como Santa Maria fez com que um médico, que se tornou monge, comesse as comidas igual aos outros monges, que para ele tinham o gosto muito ruim".
} 


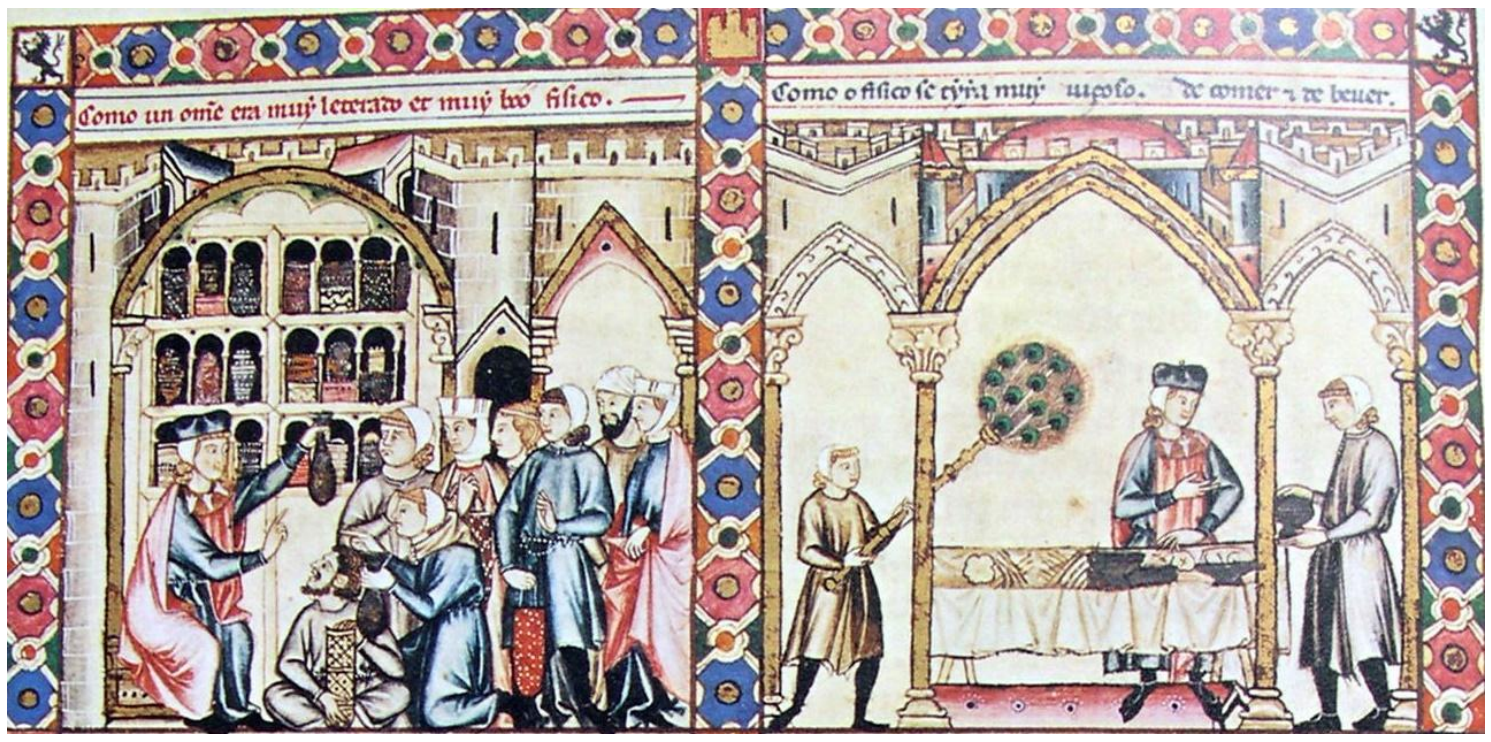

Imagem 02: cantiga 88, As Cantigas de Santa Maria - Códice Rico de El Escorial T-I-1 - E2, f. 129v, miniaturas $1 \mathrm{~A}$ e $2 \mathrm{~B}$

Na primeira vinheta se verifica um pequeno grupo à direita, formado por homens e mulheres, que prestam atenção em um homem que segura uma ampola contendo urina que está sendo examinada pelo médico (MENÉNDEZPIDAL, 1986, p. 176). As outras pessoas seguram cada um suas ampolas contendo o líquido esperando para que o médico as analise. No rótulo está escrito: "Como um home era mui leterado e mui bõo físico" (MONTERO SANTALHA, 2002, p. 65) ${ }^{6}$. Para que a fama do médico seja realçada, o miniaturista recorreu a uma estratégia estilística interessante: agrupar judeus, mouros e cristãos entre a audiência. Acredito que o homem sentado é alguém representando um judeu, devido à lateralidade do desenho que esboça um nariz adunco (BAGBY Jr, 1987, p. 239), característica estereotipada frequentemente atribuída a esse grupo minoritário nas CSM. Outro personagem chama atenção pelo uso de um turbante. Trata-se de uma figura masculina no canto direito da vinheta (MENÉNDEZ-PIDAL et al., 1981, p. 144). Ainda se olharmos as tocas sobre as cabeças, podemos perceber que os demais personagens são cristãos, devido ao tipo de acessório, formando a maioria do

\footnotetext{
6 "Como um homem era muito letrado e muito bom médico".
} 
grupo. O prestígio por ser um bõo físico é expressado na iconografia pela exposição de um herbário ao fundo, uma espécie de cristaleira contendo fármacos.

Há um salto na narrativa entre as vinhetas, o que as torna dependentes da legenda, pois o único objeto que marca a transição de um ato ao outro é a manutenção dos trajes do médico. Tanto o tempo quanto o espaço são alterados de forma repentina. Somente com o rótulo se sabe que se trata do mesmo homem da história reconhecido por gostar de comer e beber com satisfação: "Como o físico se t-ia [tynya] mui viçoso de comer e de bever" (MONTERO SANTALHA, 2002, p. 65)7. Para demonstração da gula, o miniaturista compôs a mesa com baixelas de comida e pães, sempre apresentando fartura. Há dois serviçais na sala: um que está com um leque abanando o médico, e outro que está, aparentemente, servindo-o uma taça de vinho. Os versos 16 e 17 contêm a informação de que o médico se satisfazia ao se alimentar, "E porque acostumado fora de mui ben jantar" (ALFONSO X, 1959, p. 253). A dependência em relação ao poema parece ser mais evidente quando é preciso reelaborar a iconografia para "encaixar-se" com a narrativa textual.

A terceira cantiga que utilizo como exemplo é mais curta que as demais e apresenta uma história sem muitos elementos entrecruzados ou sobrepostos, isto é, em resumo, a cantiga tem um enredo simples. Na epígrafe lê-se: “Esta é como Santa María amẽaçou o bispo que descomungou o crérigo que non sabía dizer outra missa senôn a súa" (ALFONSO X, 1959, p. 95). Trata-se da história de um clérigo que só sabia celebrar uma missa. Por isso, foi acusado pelo bispo da diocese em uma audiência e o clérigo foi obrigado a deixar aquela comunidade. No entanto, naquela mesma noite, Maria apareceu para o bispo mandando-o que revertesse sua decisão, senão ela o queimaria no inferno, no que foi

\footnotetext{
7 "Como o médico tinha muita satisfação em comer e beber".
} 
prontamente atendida. Com medo da punição, o bispo autorizou o clérigo a continuar ministrando apenas um tipo de celebração missal.

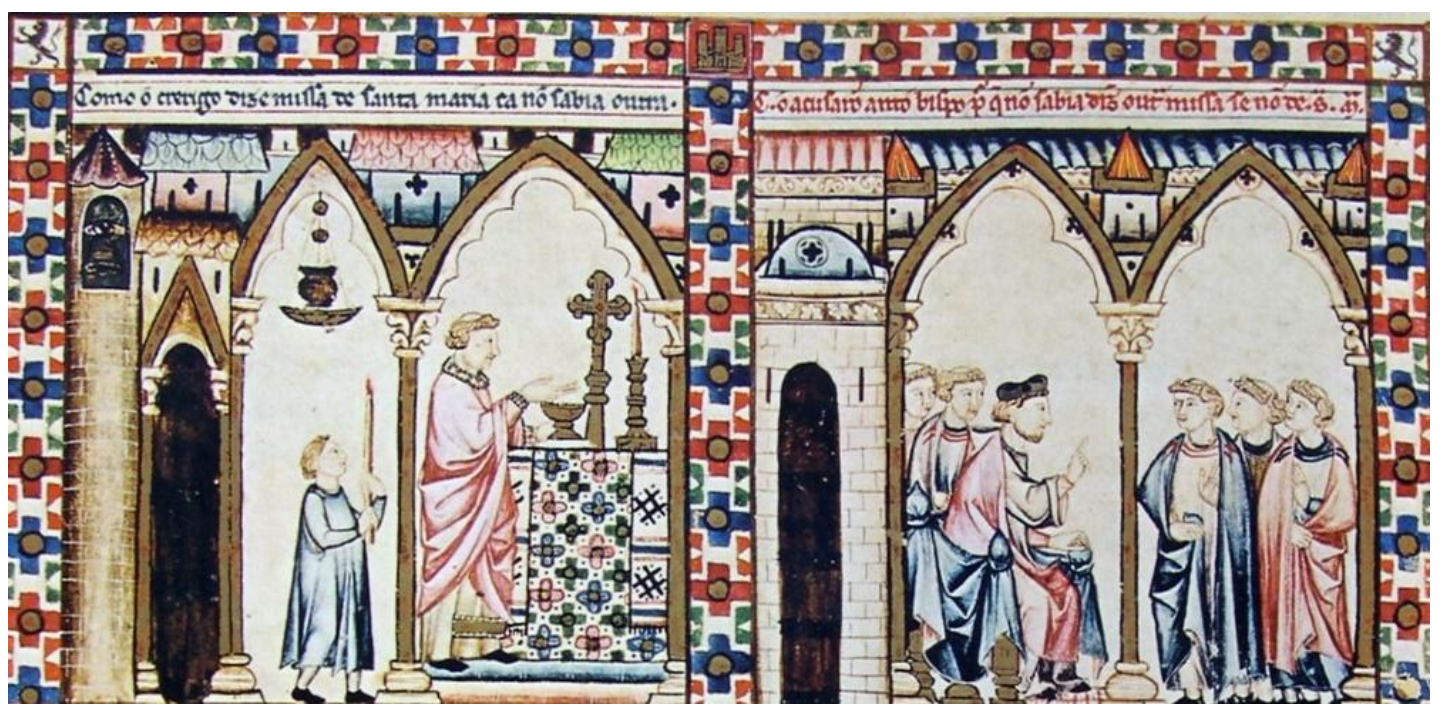

Imagem 03: cantiga 32, As Cantigas de Santa Maria - Códice Rico de El Escorial T-I-1 - E2, f. 47v, miniaturas $1 \mathrm{~A}$ e $2 \mathrm{~B}$

No primeiro rótulo está escrito que o clérigo não conhecia outra missa senão a de Santa Maria, "Como o crérigo dize missa de Santa Maria, ca nom sabia

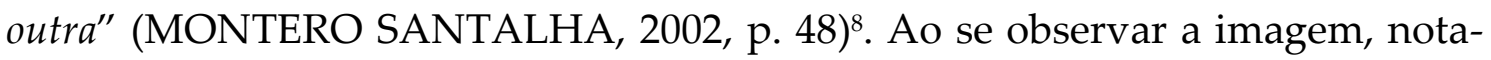
se que não há referências icônicas à figura de Santa Maria, pois o altar não é dedicado à Virgem. Sabe-se, claro, que se trata de uma igreja, devido aos objetos: o incensário no teto e a sineira à esquerda, o acólito ao centro segurando uma vela, além da liturgia referente ao altar, como o cálice, o castiçal e a própria cruz. Porém, existe forte dependência à legenda para que a mensagem fique clara para o espectador, visto que a banalidade da cena não sugere que se trata de um clérigo limitado em sua formação sacerdotal. $O$ mesmo ocorre com a imagem seguinte. Não há nenhum elemento que marque a transição da narrativa, nem mesmo as roupas do clérigo da primeira vinheta. No rótulo está escrito que há uma acusação ao bispo sobre a conduta do clérigo, "Como o acusarom ant' o bispo porque nom sabia dizer outra missa senom de Santa

\footnotetext{
8 "Como o clérigo disse missa de Santa Maria porque não sabia outra".
} 
Maria" (MONTERO SANTALHA, 2002, p. 49) ${ }^{9}$. A imagem, no entanto, não destaca nenhuma informação que caracterize o enredo da cantiga.

O repertório iconográfico é bastante singelo e não expressa claramente a sequência de acontecimentos da história. Sabe-se que de fato houve uma inculpação do clérigo, lida nos versos 17 e 18: “Onde ao Bispo daquele bispado en que el morava foi end' acusado" (ALFONSO X, 1959, p. 95), mas o miniaturista optou por representar uma hierarquia horizontal, da esquerda para direita, em que um personagem sentado, com o dedo em riste, - neste caso, o bispo recrimina outra pessoa cuja reação é um gesto de recepção do acusador - ou seja, a palma da mão esquerda aberta e direcionada ao presbítero.

Por fim, vale a pena reproduzir a última vinheta da cantiga 32:

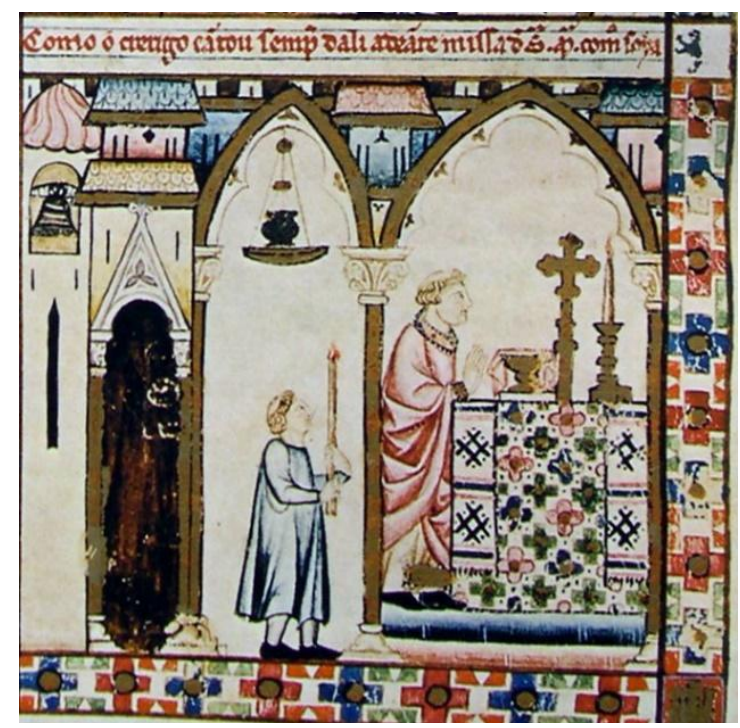

Imagem 04: cantiga 32, As Cantigas de Santa Maria - Códice Rico de El Escorial T-I-1 - E2, f. 47v, miniaturas 6B.

Há, como podemos verificar, uma replicação da primeira vinheta, dado que todos objetos estão justapostos e os personagens estão nas mesmas posições que na primeira imagem, salvo a mudança das mãos e uma leve inclinação do clérigo. No rótulo está escrito: “Como o crérigo cantou sempre dali adeante missa de

\footnotetext{
9 "Como o acusaram diante do bispo porque não sabia dizer outra missa senão a de Santa Maria".
} 
Santa Maria como soía" (MONTERO SANTALHA, 2002, p. 49) ${ }^{10}$. Esse tipo de recurso iconográfico é comum em outras cantigas, principalmente quando se quer marcar que houve movimento dos personagens no mesmo espaço, mas, neste caso, a duplicação entre miniaturas reforça a ideia de que a legenda pode ganhar protagonismo narrativo por conta de uma limitação da iconicidade em sua dimensão visual.

\section{CONCLUSÃO}

Qual a função de fato das legendas que ocupam apenas uma franja nas miniaturas, ao menos, as que destaquei neste trabalho? Seria apenas uma sinopse daquilo que se enuncia na imagem? Ou seria uma complementação interdiscursiva? Obviamente que apenas a seleção de algumas imagens não pode responder a problemas que perpassam toda a obra alfonsina, em especial a dos códices historiados. Ainda assim, é possível refletir sobre as relações texto-imagem a partir das iconografias elencadas.

Primeiro, partirei de uma questão como linha-mestra da argumentação: seriam as imagens complementares ao texto? Segundo Sánchez Ameijeiras (2002), taxativamente não: mesmo que as imagens acompanhem o texto, não constituem uma ilustração deste, “... senón que mostran, por medio dos recursos específicos da retórica figurativa, un relato ou unha loa visual paralelas, que en ocasións glosan novos contidos, e noutras, en cambio, omiten motivos literários" (SÁNCHEZ AMEIJEIRAS, 2002, p. 251). Embora esta sentença esteja se referindo ao texto poético, a afirmação pode se estender às legendas, porque a liberdade visual parece ter grande autonomia em relação a qualquer enunciado textual nas CSM. Se tomarmos o exemplo da cantiga 17, na primeira vinheta, percebemos a variedade de elementos contidos na cena -

10 "Como o clérigo cantou sempre dali em diante missa de Santa Maria como sabia". 
desde o ponto de vista material, como a cama e outros objetos, até mesmo a extemporânea presença do Diabo. Mas o redator responsável pelo rótulo comunica que se trata de um jovem e sua mãe, tendo a gravidez como resultado dessa relação. Isso evidencia que o processo de escolha daquilo que deve ser narrado tem uma função didática ao sublinhar que o ato sexual advém de um relacionamento incestuoso. Trata-se de um alerta ao espectador sobre o pecado, a proibição e as consequências do vício. O mesmo ocorre na segunda vinheta, posto que não há uma motivação para o assassinato da criança, diferentemente do texto poético em que se culpa o demônio como provocador do crime, “... ũa dona mui de coraçôn amou a Madre de Déus; mas entôn sofreu que fosse do démo tentada" (ALFONSO X, 1959, p. 52). Nas duas vinhetas da cantiga 17, não houve preocupação do miniaturista em demonstrar a devoção da dama à Maria, optando por sequenciar apenas os delitos da dama.

Segundo, ao mesmo tempo em que se verifica a autonomia pictórica, em contraste com a vinheta 17, as imagens da cantiga 88 fazem uso do recurso narrativo continuado e, ao mesmo tempo, cíclico $^{11}$, ao recolocar o personagem central na miniatura seguinte, mas modificando o cenário. Porém, a iconicidade dos acontecimentos é dependente das legendas, isso porque a caracterização de alguém como "bom médico" e, ao mesmo tempo, "glutão", pode não fazer sentido para o espectador sem o recurso textual. As legendas, portanto, têm também função de ordenamento para evitar a autonomia completa da imagem, impedindo a livre interpretação do espectador. A fragilidade da vinheta 2 da cantiga 88 impõe à legenda o peso interpretativo, desequilibrando a relação texto-imagem da miniatura. Isso contrasta com a cantiga 17 em que a sequência

\footnotetext{
11 "As tres posibilidades teóricas de mostrar a acción nas imaxes son: monoescénica, de modo que toda unha historia está descrita cunha soa imaxe, cunha soa representación de cada protagonista; continua, cando a historia está contada nun único marco, pero os protagonistas poden aparecer máis dunha vez; e cíclica, cando unha serie de imaxes describen outra serie de episodios narrativos" (SÁNCHEZ AMEIJEIRAS, 2002, p. 253).
} 
sexo, parto e infanticídio recolocam a atenção do público sobre as imagens, exigindo do redator das legendas um "esclarecimento" sobre o ocorrido.

A cantiga 32 é um exemplo de desassociação entre texto e imagem. Tratase de um enredo com uma longa tradição entre as fontes de milagres marianos medievais, conhecidas vulgarmente como milagre do "clérigo ignorante"12 (FILGUEIRA VALVERDE, 1985, p. 66). Essa informação pode sugerir que o redator das legendas poderia ter conhecido o relato sem mesmo ter consultado sistematicamente o manuscrito da cantiga. Trata-se de um dissenso evidente cujas soluções pictóricas se "descolam" do enunciado textual. Como se trata de uma miniatura sem impacto visual, diferentemente da cantiga 17, a audiência pode experienciar certa neutralidade do discurso imagético, pois trata-se de um espaço em que se celebra uma missa, e não um ato sexual, como visto antes.

Ao deslocar o campo textual para o campo imagético, a relação textoimagem se torna sempre dialética, como já propôs Rodríguez Barral (2007), ao assinalar que essa dependência não é direta entre o texto e o representado nas miniaturas, pelo contrário “... éstas, atendiendo a una lógica propia, adquieren un considerable grado de autonomía, de tal modo que su secuencia narrativa puede modificar, tanto por adición como por omisión, el contenido del texto" (RODRÍGUEZ BARRAL, 2007, p. 214). Mas há um longo caminho para a discussão, uma vez que são necessários estudos comparativos sistemáticos que ponham em relevo não apenas os enunciados textuais e imagéticos, mas também as relações interdiscursivas, as construções de sentidos, as descontinuidades, as negociações e os paradoxos inerentes a um manuscrito elaborado por tantas mãos.

\footnotetext{
${ }^{12}$ Há referências a esse relato em diferentes coleções de milagres medievais: Thott (Copenhagen, Royal Library, ms Thott, 128); Phillips (Chicago, University of Chicago, Phillipps, ms 25142); Gil de Zamora (Madrid, Biblioteca Nacional, ms 9503) Gil de Zamora (Madrid, Biblioteca Nacional, ms 9503); Biblioteca Mariale 3 (London, BL, Additional, ms 35112, ff. 21-80; 90-94); Lisbon Mariale (Lisbon, B.N., ms Alcobacense, 149); Madrid Mariale (Madrid, B.N., ms 110); entre outros.
} 


\section{REFERÊNCIAS}

ALFONSO X, O SÁBIO. As Cantigas de Santa Maria - Códice Rico de El Escorial T-I-1 - E2. Madrid: Edilán, 1979.

BAGBY Jr, Albert. I. The figure of the jews in the cantigas. In: KATZ, Israel J.; KELLER, John E. (Orgs). Studies on the Cantigas de Santa Maria: Art, Music, and Poetry. Madison: Associate Editors Samuel G. Armistead \& Joseph T. Snow, 1987. p. 234-245.

CHICO PICAZA, María Victoria. La relación texto-imagen en las Cantigas de Santa María, de Alfonso X el Sabio. Reales Sitios: Revista del Patrimonio Nacional, no 87, p. 65-72, 1986.

CORTI, Francisco. Retórica y semiótica visuales en la ilustración de las Cantigas de Santa María. Alcanate, no 7, p. 215 -233, 2010-2011.

FERNÁNDEZ FERNÁNDEZ, Laura. Manuscritos iluminados: artífices, espacios y contextos productivos In: AVENOZA, Gemma et al. La producción del libro en la Edad Media - una visión interdisciplinar. Madri: Silex, 2019. p. 191-206.

FILGUEIRA VALVERDE, José. As Cantigas de Santa Maria. Madri: Castalia, 1985.

GARCIA CUADRADO, Amparo. El códice de las historias de las cantigas - imagen y comunicación en el manuscrito miniado. Miscelánea Medieval Murciana, n.o 17, p. 201241, 1992.

GUERRERO LOVILLO, José. Las Cantigas - estudio arqueológico de sus miniaturas. Madrid: Instituto Diego Velásquez, 1949.

KELLER, John Esten. Verbalization and visualization in the Cantigas de Santa María. Estudios de Hispanófila, n.ํㅜ 36, 221-226, 1976.

MARIÑO PAZ, Ramón. Hipercorrección y castellanismo en las leyendas de las miniaturas de los códices T y F de las Cantigas de Santa María. Estudis Romànics, n. ${ }^{\circ}$ 40, 2018, p. 37-57.

MENÉNDEZ-PIDAL, Gonzalo e BERNIS, Carmen. Las Cantigas - la vida en el siglo XIII - segundo la representación iconográfica. Cuadernos de la Alhambra, vol. 2, n. ${ }^{\circ}$ 14, p. 89-160, 1981.

MENÉNDEZ-PIDAL, Gonzalo. La España del siglo XIII leída en imágenes. Madrid: Real Academia de la Historia, 1986.

MENÉNDEZ-PIDAL, Gonzalo. Los manuscritos de las cantigas - cómo se elaboró la miniatura alfonsí. Boletín de la Real Academia de la Historia, n.. 150, p. 25-51, 1962.

METTMANN, Walter. As Cantigas de Santa Maria de Alfonso X. 4 vols. Coimbra: Acta Universitatis Conimbrigensis, 1959-1972.

MONTERO SANTALHA, José-Martinho. As legendas das miniaturas das Cantigas de Santa Maria - códice T, 2ª parte. Agália, nº 69-70, p. 43-88, 2002.

MONTERO SANTALHA, José-Martinho. As legendas das miniaturas das Cantigas de Santa Maria - códices T e F In: RODRÍGUEZ FERNÁNDEZ, José Luis (Org.) Estudos 
dedicados a Ricardo Carvalho Calero. 2 Vols. Galícia: Parlamento de Galicia; Universidade de Santiago de Compostela, 2000. p. 507-552.

MONTOYA MARTÍNEZ, Jesús. Algunas precisiones de las Cantigas de Santa María In: KATZ, Israel J.; KELLER, John E. (Orgs). Studies on the Cantigas de Santa Maria: Art, Music, and Poetry. Madison: Associate Editors Samuel G. Armistead \& Joseph T. Snow, 1987. p. 367-386.

PARKINSON, Stephen; JACKSON, Deirdre. Collection composition and the compilation in the Cantigas de Santa María, Portuguese Studies, Londres, n. ${ }^{2}$ 22, p. 159172, 2006.

RODRÍGUEZ ALEMÁN, María del Mar. Una aproximación al códice rico de las Cantigas de Santa María del monasterio del Escorial - miniatura, poema y glosa. Revista de Poética Medieval, n.ำ11, p. 53-92, 2003.

RODRÍGUEZ BARRAL, Paulino. La Dialéctica - texto-imagen a propósito de la representación del judío en las Cantigas de Santa María de Alfonso X. Anuario de Estudios Medievales, vol. 1, n.․․ 37, p. 213-243, 2007.

SÁNCHEZ AMEIJEIRAS, Rocío. Imaxes e teoria da imaxe nas Cantigas de Santa Maria In: FIDALGO FRANCISCO, Elvira. As Cantigas de Santa Maria. Vigo: Xerais, 2002. p. 246-330.

SCARBOROUGH, Connie L. Verbalization and Visualization in ms. T.L.l. of the Cantigas de Santa María In: KATZ, Israel J.; KELLER, John E. (Orgs). Studies on the Cantigas de Santa Maria: Art, Music, and Poetry. Madison: Associate Editors Samuel G. Armistead \& Joseph T. Snow, 1987. p. 135-154.

Nota do editor:

Artigo submetido para avaliação em: 27 de fevereiro de 2021.

Aprovado em sistema duplo cego em: 26 de maio de 2021. 